\title{
Petrochemistry and Petrogenetic Features of Metasedimentary Rocks of Igangan Area, Southwestern Nigeria
}

\author{
Olusegun G. Olisa ${ }^{*}$, Olugbenga A. Okunlola², Ayotunde A. Omitogun² \\ ${ }^{1}$ Department of Geology, PAULESI, University of Ibadan, Ibadan, Nigeria \\ ${ }^{2}$ Department of Geology, University of Ibadan, Ibadan, Nigeria \\ Email: ^segolisa@yahoo.com
}

How to cite this paper: Olisa, O.G., Okunlola, O.A. and Omitogun, A.A. (2018) Petrochemistry and Petrogenetic Features of Metasedimentary Rocks of Igangan Area, Southwestern Nigeria. Journal of Geoscience and Environment Protection, 6, 49-66. https://doi.org/10.4236/gep.2018.64004

Received: December 6, 2017

Accepted: March 30, 2018

Published: April 2, 2018

Copyright $\odot 2018$ by authors and Scientific Research Publishing Inc. This work is licensed under the Creative Commons Attribution International License (CC BY 4.0).

http://creativecommons.org/licenses/by/4.0/

\begin{abstract}
The study was carried out to delineate the geochemistry of unstudied meta-sedimentary rocks in the Igangan sheet $240 \mathrm{NW}$. Geological field mapping was undertaken to delineate the different metasedimentary rocks; three different metasedimentary rocks were observed and 17 samples were analyzed using ICP-AES/MS to obtain elemental concentrations. Geochemical analytical results revealed average concentration (\%) of 74.5, 12.66, 1.99, 4.23, and 3.59 for $\mathrm{SiO}_{2}, \mathrm{Al}_{2} \mathrm{O}_{3}, \mathrm{Fe}_{2} \mathrm{O}_{3}, \mathrm{Na}_{2} \mathrm{O}$ and $\mathrm{K}_{2} \mathrm{O}$ respectively. Trace elemental average concentrations ( $\mathrm{ppm}$ ) for selected trace elements in the metasediments are as: $\mathrm{U}(0.4-4.8 \mathrm{ppm}, 2.39)$, Th $(0.9-25.60 \mathrm{ppm}, 10.38), \mathrm{Ni}(0.1-17.70 \mathrm{ppm}$, 7.40), Sr (37 - 124 ppm, 81.75), Ba (55 - 1228 ppm, 620.31), Sn (1.4 - 4.8), Be (1 - $11 \mathrm{ppm}, 3.31)$, Li (2.6 - $48.50 \mathrm{ppm}, 23.28), \mathrm{Rb}$ (32 - $376.3 \mathrm{ppm}, 140.16)$, Ta (0.5 - 65.20 ppm, 12.48), Nb (7.76 - $47.5 \mathrm{ppm}, 23.82)$ and Cs ( 0.8 - $33.30 \mathrm{ppm}$, 8.33). REE patterns of all samples are parallel to sub-parallel, LREE-enriched, with weak to distinct negative $\mathrm{Eu}$ anomalies and weakly fractionated HREE segments. Source rocks of the metsediments underwent low to moderate chemical weathering and metasediments are derivatives of felsic igneous sources.
\end{abstract}

\section{Keywords}

Phyllite, Sediment Recycling, Depositional Regimes

\section{Introduction}

The study area is part of the Basement Complex of southwestern Nigeria; it is located in Igangan sheet 240 North West, Southwestern Nigeria; longitude $3^{\circ} 00^{\prime \prime}$ $-3^{\circ} 15^{\prime \prime}$ and latitude $7^{\circ} 45^{\prime \prime}-8^{\circ} 00^{\prime \prime}$. The study area has an area extent of about 829 
$\mathrm{km}^{2}$ (Figure 1) and is a relatively unstudied area in Nigeria with paucity of information on the geology and geochemistry of rock units in the area.

The dominant rocks in the area are the meta-sediments which include quartzite, mica schist and phyllites underlain by variably migmatised tonalitic and granitic gneisses while members of Late- to Post-Pan African granitoids intruded and cut the fabrics of the meta-sediments outcropping as potassic porphyritic granites, which is a scenario that has also been reported from other parts of southwestern Nigerian schist belt [1].

[2] explained that the area is composed mainly of mica schists with quartzites and metamorphism is higher in grade than in most northern schist belts, with pelitic rocks containing biotite, garnet, staurolite and locally sillimanite.

Several studies have been carried out on metasedimentary rocks in different areas in Nigeria and around the world. For example, [3] studied the geochemical composition and petrogenesis of schists and amphibolites of parts of sheets 203 (Lafiagi) SW and 224 (Osi) NW. Petrographic and geochemical studies show that the metasediments are para-schists of arkosic to greywacke parentage which were sourced from a moderately weathered feldspathic igneous rock Derivation of the schists from $\mathrm{K}$ feldspar-rich protoliths is indicated by the enhancement of $\mathrm{Ba}$ over $\mathrm{Rb}$ while the presence of significant amount of mafic constituents is signified by relatively high amount of $\mathrm{Cr}$ and, sometimes, $\mathrm{Ni}$. They suggested that the presence of quartzite intercalated with other metasediments is an indication of alternate flow regimes where heavy and light sediments were deposited at different times; such has also been described by [4] in some other parts of the Nigerian basement complex.

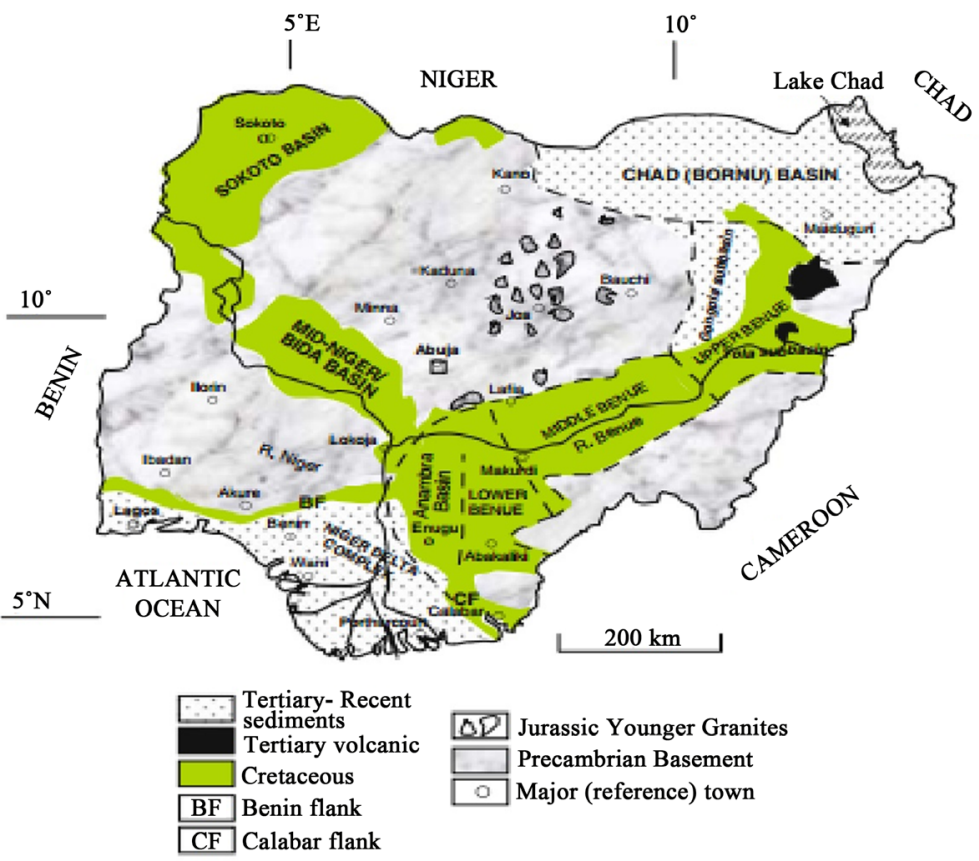

Figure 1. Geological sketch map of Nigeria showing the major geological components Basement complex, Younger Granite and sedimentary basin (Adapted from [8]). 
[5] examined the metavolcanic and metasedimentary rocks from the Tsaliet and Tembien Groups in the Werri district of northern Ethiopia to determine their tectonic setting of eruption, provenance and source area weathering conditions. They reported amongst other observations that the $\mathrm{Sm} / \mathrm{Nd}$ ratios reveal a model age of $0.96 \mathrm{Ga}$ which is indicative of derivation from juvenile Neoproterozoic mantle.

[6] also studied the geochemical characterization of the protoliths and the tectonic implications of the metasedimentary rocks of the northern portion of the Macururé Domain. Greywackes protoliths dominate with some subordinate shales and arkoses; major, trace and rare-earth element chemistry indicates a source with an average upper crustal composition for the protoliths of metasedimentary rocks, a mixed source detritus was also suggested for the rocks in the study area.

[7] examined the compositional characteristics and petrogenetic features of metasediments of Ijero-Ekiti area, southwestern Nigeria. They reported a sedimentary protolith for the investigated rocks based on variation plots and trace element concentrations in quartzite units of the study area suggests derivation of the sedimentary protolith from weathering of granitic rocks.

The present study is therefore based on delineation of the geochemistry, provenance and sediment recycling in the metasedimentary rocks in Iganagan sheet $240 \mathrm{NW}$.

\section{Materials and Methods}

The methods adopted in carrying out the research include desk study of related subjects, geological field mapping, sampling and geochemical analyses. Geological mapping of the study area was done on scale 1:50,000. Random samplings of big, fresh, representative rocks were carried out and samples for thin-section and geochemical analyses were obtained. 17 samples were selected and analyzed for their major, trace and rare earth elements compositions using ICP MS/AES. The samples were pulverized at the Department of Geology, University of Ibadan and analyses were carried out at the Bureau Veritas Mineral Commodities (BVM) Canada.

\section{Results and Discussion}

\subsection{Local Geological Setting}

In the study area, different types of metasediments were observed and mapped (Figure 2) ranging from:
1) Phyllites,
2) Quartz schists,
3) Quartz muscovite schist and,
4) Quartz biotite schists.

The phyllites occur as low lying leucocratic sub-weathered bodies in the northwestern flank of the study area, the quartz muscovite schists occur as a 


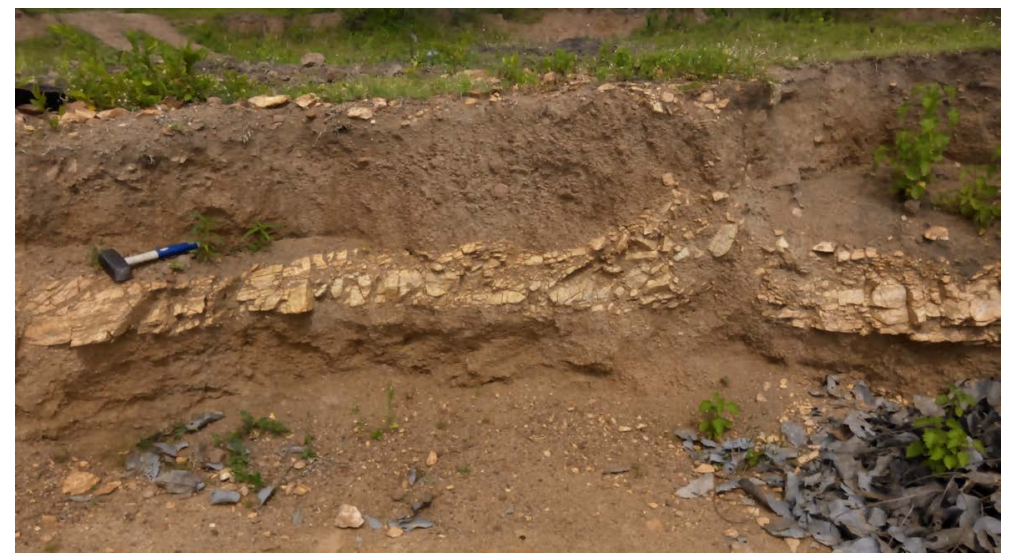

(a)

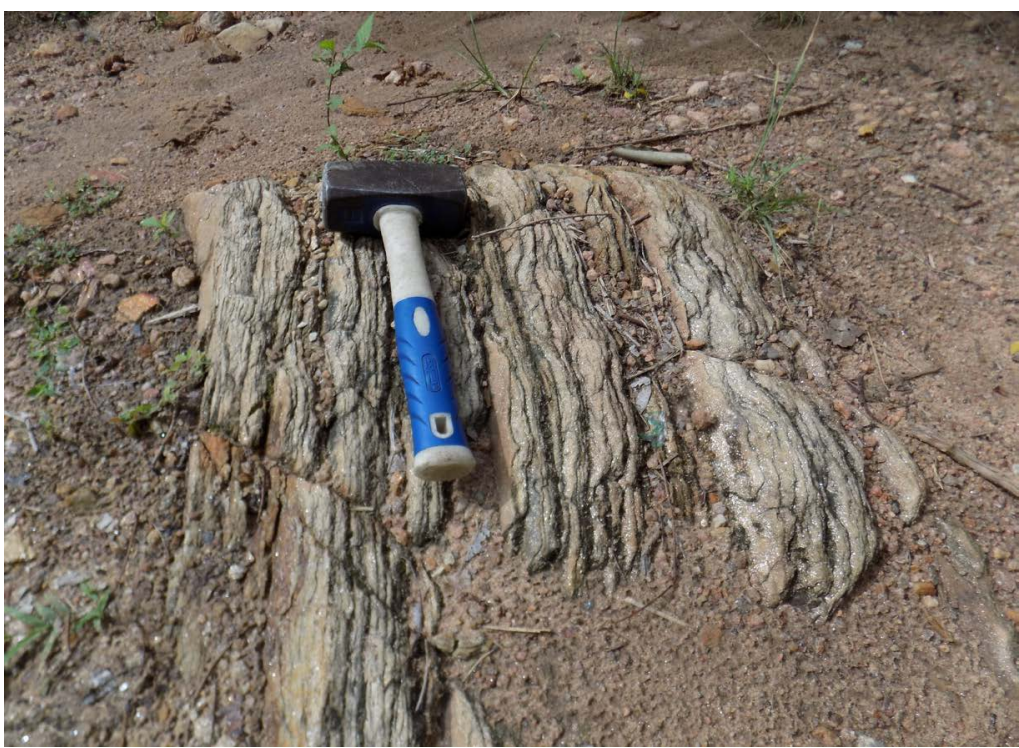

(b)

Figure 2. (a) Quartz remnant in quartzite intercalated with schist; and (b) Quartz mica schist.

leucocratic ridge in the central part of the study area; the quartz biotite schist occur as melanocratic outcrops in the western flank of the study area while the quartzite occurs as intercalations with schists in different areas in the study area. The quartzites are fairly weathered in some areas, poorly jointed and they occur as boulders and pods. The metasediments have been intruded by fine to medium grained potassic porphyritic granites and biotite granites as well as pegmatite veins (Figure 3).

\subsection{Petrography}

The phyllites in the study area is dominanted by semi equigranular grains of quartz with scarce feldspar while the quartz mica schists are dominated by euhedral to subhedral grains of quartz and muscovite/biotite with low quantities of feldspar (Figure 4(a), Figure 4(b)). 


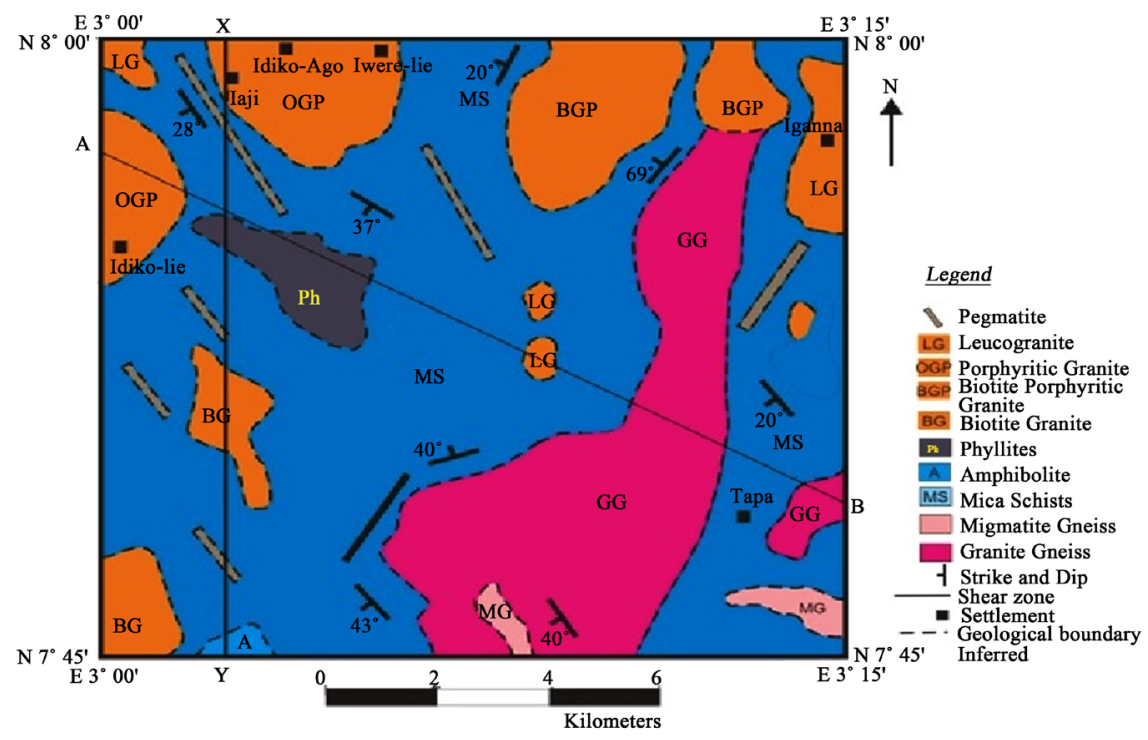

Figure 3. Geological map of the study area.

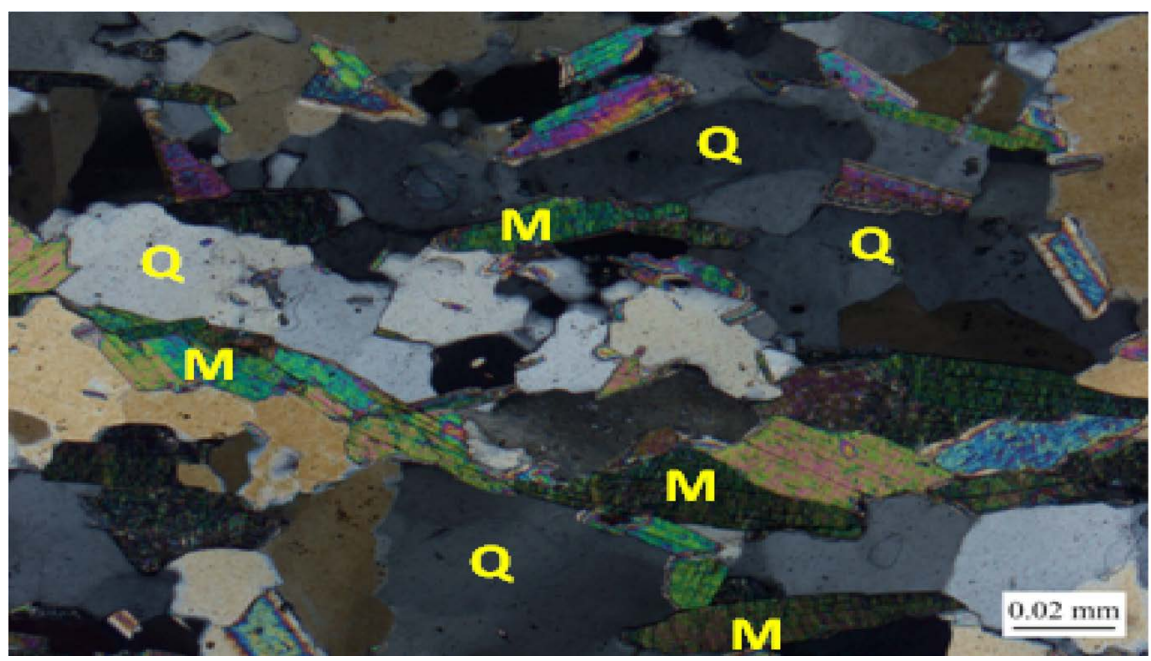

(a)

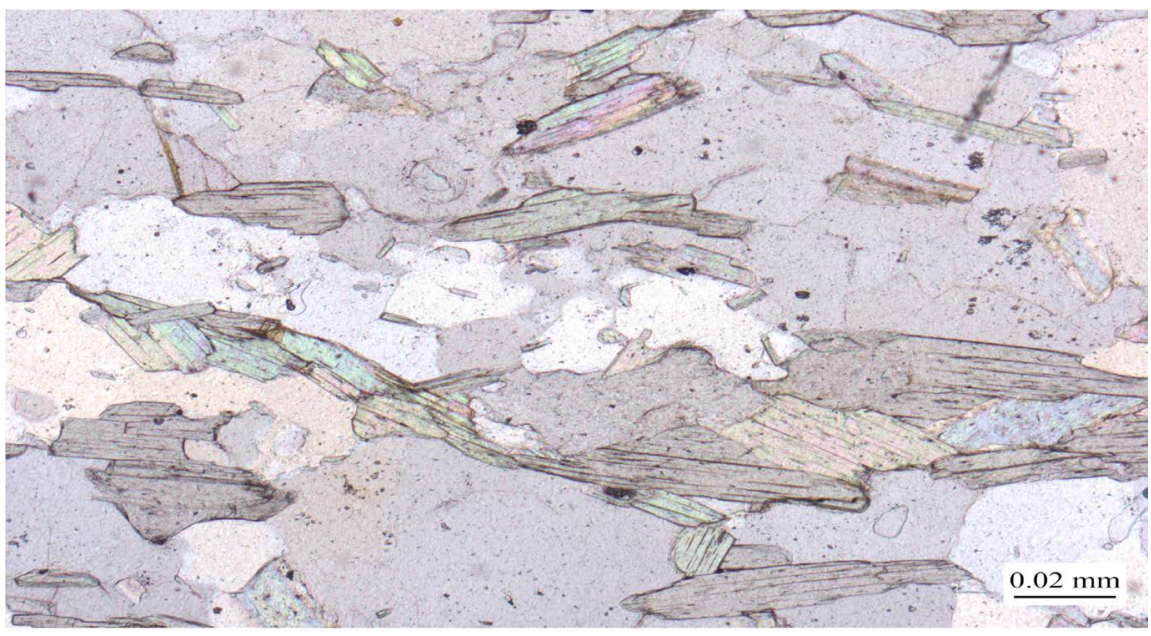

(b) 


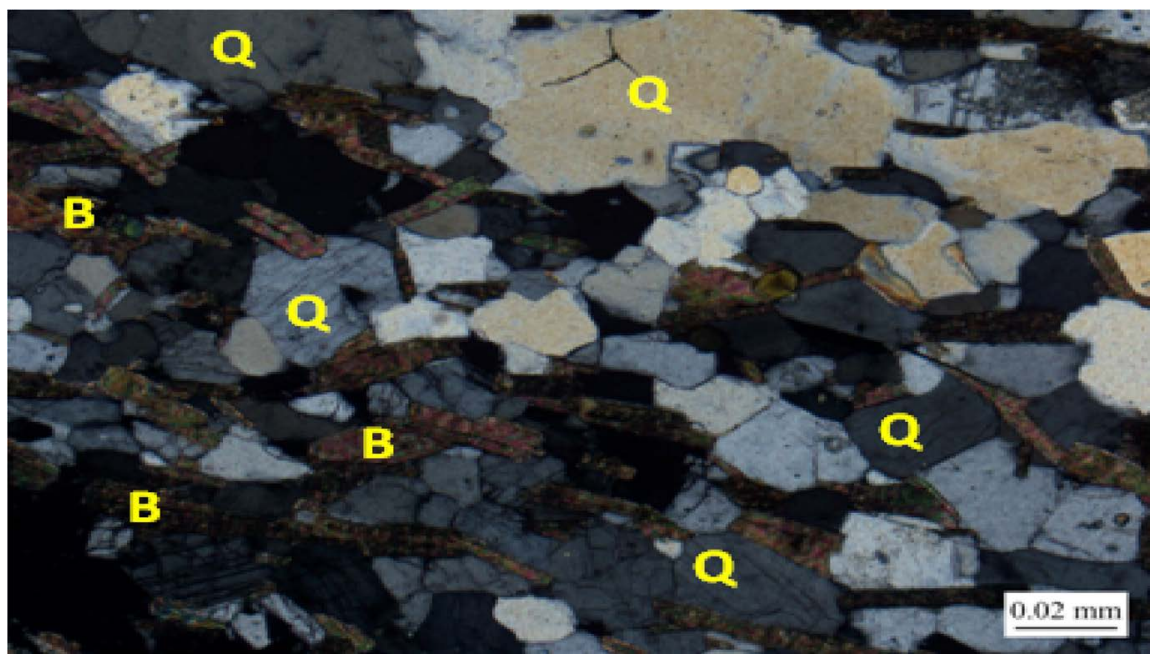

(c)

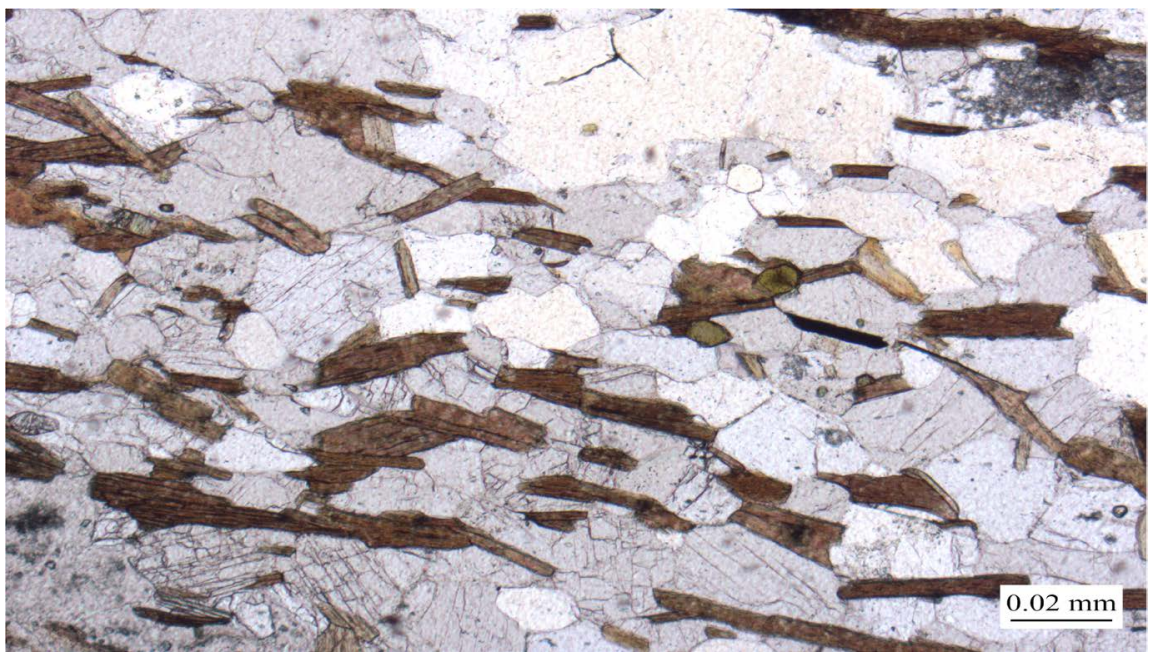

(d)

Figure 4. (a) (b) Photomicrographs of quartz biotite schist, (c) (d) Photomicrographs of quartz muscovite schist.

\subsection{Major Elements}

The metasediments reveals a wide range for the major elements; they are siliceous (Table 1); with $\mathrm{SiO}_{2}$ ranging from $68.04 \%$ to $80.00 \%$ (mean $74.96 \%$ ), the $\mathrm{TiO}_{2}$ ranges from $0.02 \%$ to $0.68 \%$ (mean $0.21 \%$ ), the $\mathrm{Al}_{2} \mathrm{O}_{3}$ ranges from $10.69 \%$ to $18.85 \%$ (mean, $12.66 \%$ ) while the range and mean content of other oxides in the metasediments are as follows; $\mathrm{Fe}_{2} \mathrm{O}_{3}(0.36 \%$ to $4.53 \%, 1.99 \%), \mathrm{MgO}(0.01 \%$ to $0.32 \%, 0.54 \%), \mathrm{CaO}(0.01 \%$ to $2.50 \%, 0.96 \%), \mathrm{Na}_{2} \mathrm{O}(0.32 \%$ to $7.18 \%, 4.23 \%)$, $\mathrm{K}_{2} \mathrm{O}(1.22 \%$ to $6.71 \%, 3.59 \%), \mathrm{P}_{2} \mathrm{O}_{5}(0.01 \%$ to $0.11 \%, 0.06 \%)$ and $\mathrm{MnO}(0.01 \%$ to $0.32 \%, 0.09 \%)$.

On the plot of $\mathrm{Na}_{2} \mathrm{O}$ against $\mathrm{K}_{2} \mathrm{O}$ [9]; the phyllites mostly plot within the field of greywackes while the quartz mica schist and the quartz biotite schists plots in the field of arkose suggesting different protoliths for the metasediments (Figure $5)$ and this is supported by the plot of $\log \left(\mathrm{Fe}_{2} \mathrm{O}_{3} / \mathrm{K}_{2} \mathrm{O}\right)$ against $\log \left(\mathrm{SiO}_{2} / \mathrm{Al}_{2} \mathrm{O}_{3}\right)$ 
Table 1. Major elements of metasediments.

\begin{tabular}{ccc}
\hline & Range (\%) & Average (\%) \\
\hline $\mathrm{SiO}_{2}$ & $68.04-80.00$ & 74.96 \\
$\mathrm{Al}_{2} \mathrm{O}_{3}$ & $10.69-18.85$ & 12.66 \\
$\mathrm{Fe}_{2} \mathrm{O}_{3}$ & $0.36-4.53$ & 1.99 \\
$\mathrm{TiO}_{2}$ & $0.02-0.68$ & 0.21 \\
$\mathrm{MgO}$ & $0.01-1.53$ & 0.54 \\
$\mathrm{MnO}$ & $0.01-0.32$ & 0.09 \\
$\mathrm{CaO}$ & $0.01-2.50$ & 0.96 \\
$\mathrm{Na}_{2} \mathrm{O}$ & $0.32-7.18$ & 4.23 \\
$\mathrm{~K}_{2} \mathrm{O}$ & $1.22-6.71$ & 3.59 \\
$\mathrm{P}_{2} \mathrm{O}_{5}$ & $0.01-0.11$ & 0.06 \\
\hline
\end{tabular}

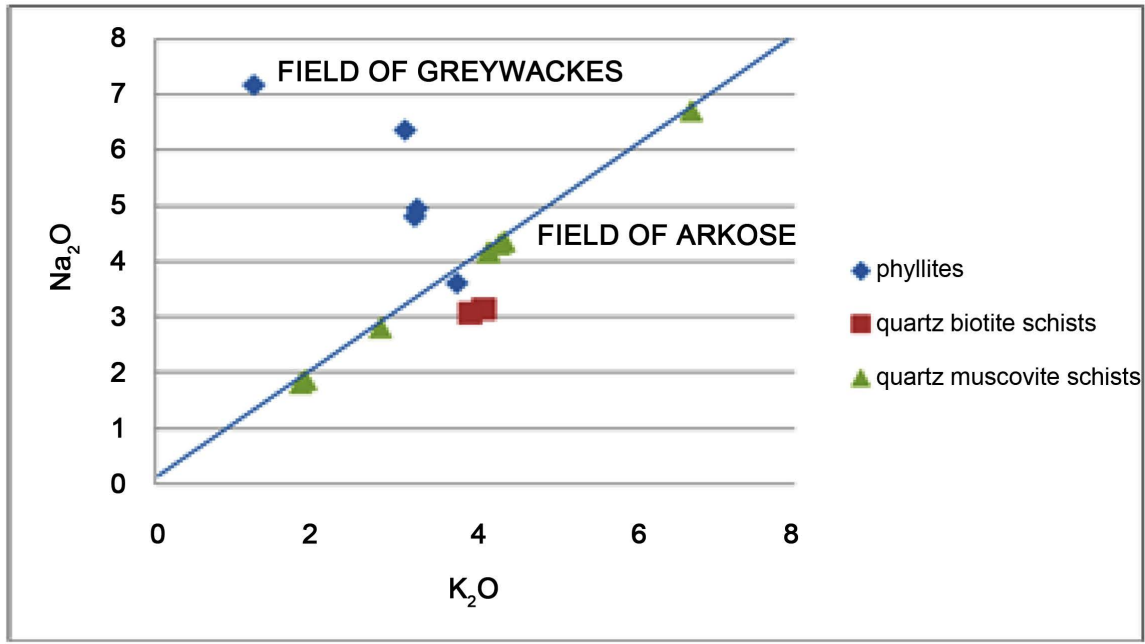

Figure 5. $\mathrm{Na}_{2} \mathrm{O}$ against $\mathrm{K}_{2} \mathrm{O}$ plot for the metasediments.

[10] in which the quartz biotite schists plots in the lithoarenite field while the quartz mica schists and phyllites plots in the arkose field (Figure 6).

The phyllite and quartz mica schist fall within the arkose field while the quartz biotite schist falls within the litharenite field; discriminant function diagram for the provenance signatures [11] reveals that the metasediments are mainly of felsic igneous provenance (Figure 7).

Compared to the international standards (e.g., PAAS, NASC, UCC, Table 2), these metasediments are characterized by low contents of $\mathrm{MgO}$ (average 0.54) and $\mathrm{Al}_{2} \mathrm{O}_{3}$ (average 12.66\%), indicative of evolution from an igneous protolith and low clay content respectively. $\mathrm{K}_{2} \mathrm{O} / \mathrm{Na}_{2} \mathrm{O}$ is generally low in the metasediments with the exception of a value of 20.97 which is possibly a reflective of secondary addition of potassium [12].

$\mathrm{SiO}_{2} / \mathrm{Al}_{2} \mathrm{O}_{3}$ varies from 3.61 - 7.48; values close to and above that of igneous rocks. This implies varying maturity in the metasediments with maturity ranging 


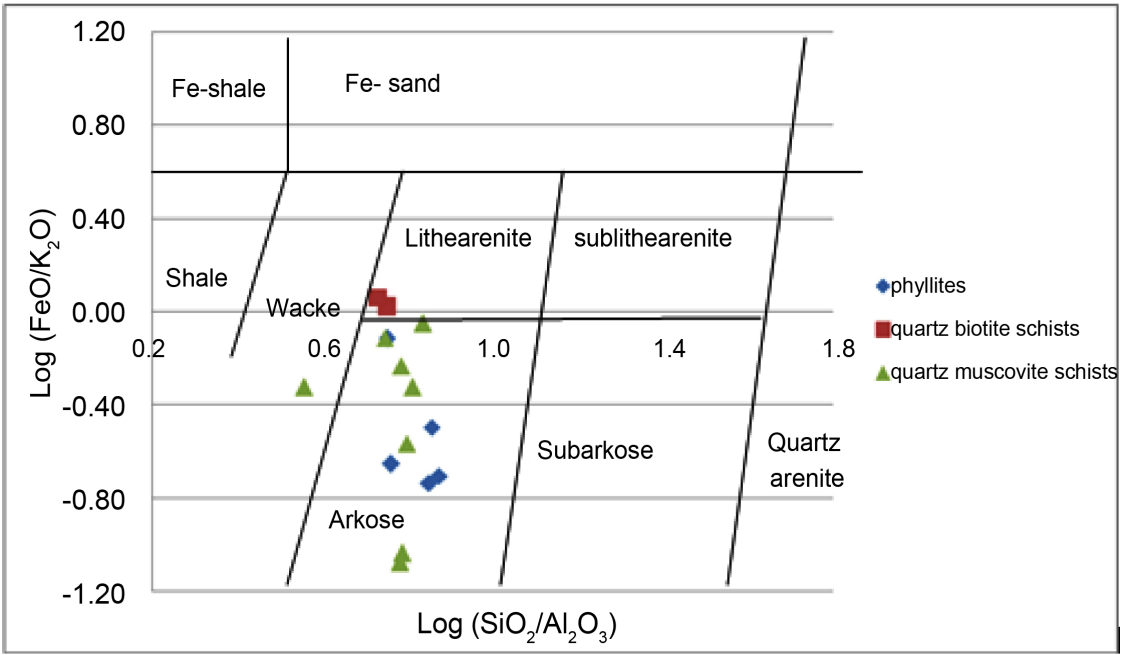

Figure 6. $\log \left(\mathrm{FeO} / \mathrm{K}_{2} \mathrm{O}\right)$ vs $\log \left(\mathrm{SiO}_{2} / \mathrm{Al}_{2} \mathrm{O}_{3}\right)$.

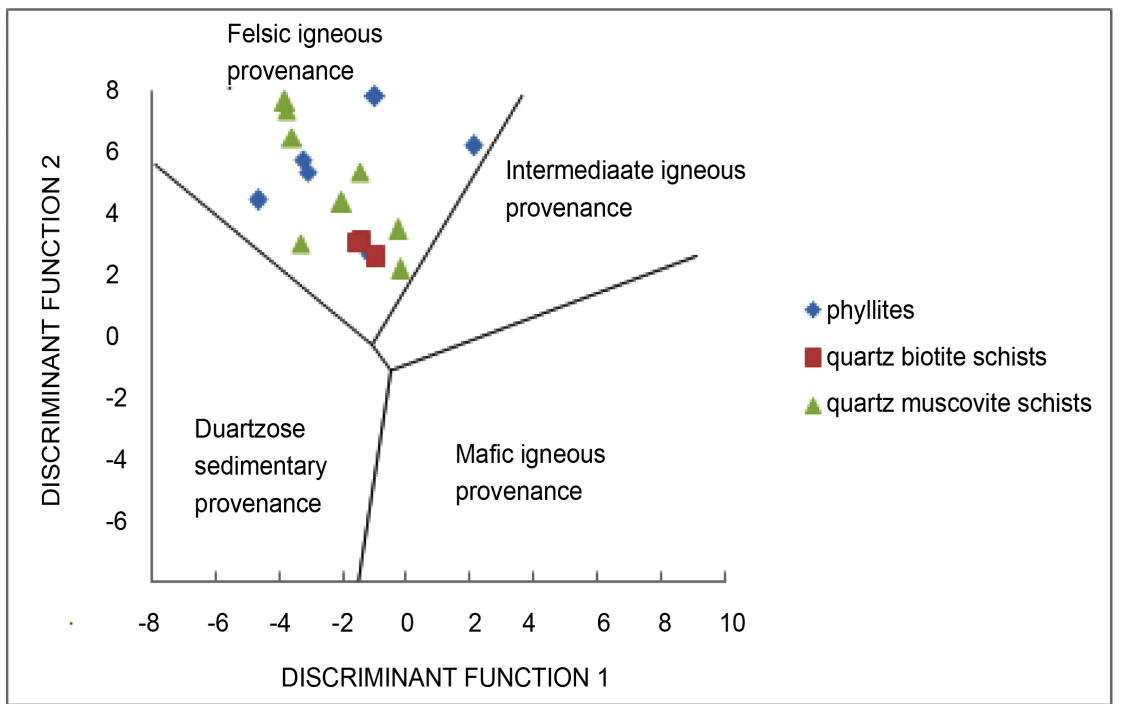

Figure 7. Discriminant function diagram for the provenance signatures using major elements (after [12]). D1 $=-1.773 \mathrm{TiO}_{2}+0.607 \mathrm{Al}_{2} \mathrm{O}_{3}+0.76 \mathrm{Fe}_{2} \mathrm{O}_{3}$ (total) $-1.5 \mathrm{MgO}+$ $0.616 \mathrm{CaO}+0.509 \mathrm{Na}_{2} \mathrm{O}-1.224 \mathrm{~K}_{2} \mathrm{O}-9.09 ; \mathrm{D} 2=0.445 \mathrm{TiO}_{2}+0.07 \mathrm{Al}_{2} \mathrm{O}_{3}-0.25 \mathrm{Fe}_{2} \mathrm{O}_{3}$ (total) $-1.142 \mathrm{MgO}+0.438 \mathrm{CaO}+1.475 \mathrm{Na}_{2} \mathrm{O}+1.426 \mathrm{~K}_{2} \mathrm{O}-6.861$.

from immature to mature since values above 5 are indicative of sedimentary maturation [13].

Chemical index of alteration (CIA) calculated [14] as molar ratio $\left[\mathrm{Al}_{2} \mathrm{O}_{3} /\left(\mathrm{Al}_{2} \mathrm{O}_{3}\right.\right.$ $\left.\left.+\mathrm{CaO}^{*}+\mathrm{Na}_{2} \mathrm{O}+\mathrm{K}_{2} \mathrm{O}\right)\right] \times 100$ where $\mathrm{CaO}^{*}$ refers to the calcium in silicates. CIA varies from 56.07 - 72.81 indicating low to moderate level of weathering of source materials. CIA is related to the $\mathrm{K}_{2} \mathrm{O} / \mathrm{Na}_{2} \mathrm{O}$ ratio with a larger percentage of samples with low CIA values are also characterized by low $\mathrm{K}_{2} \mathrm{O} / \mathrm{Na}_{2} \mathrm{O}$ values while the only sample with a very high CIA value (72.81) is characterized by a very high $\mathrm{K}_{2} \mathrm{O} / \mathrm{Na}_{2} \mathrm{O}$ value which is a reflection of expected development of $\mathrm{Al}$ concentration, severe loss of $\mathrm{Na}_{2} \mathrm{O}$ or localized sodium metasomatism. 
Table 2. Major elements of metasediments average, major and trace element compositions of studied metasediments in comparison to international references.

\begin{tabular}{|c|c|c|c|c|}
\hline & All samples & PAAS & NASC & Upper continental crust \\
\hline Reference & This study & 1 & 2 & 3 \\
\hline $\mathrm{SiO}_{2}$ & 74.96 & 62.8 & 64.8 & 66.6 \\
\hline $\mathrm{Al}_{2} \mathrm{O}_{3}$ & 12.66 & 18.9 & 16.9 & 15.4 \\
\hline $\mathrm{Fe}_{2} \mathrm{O}_{3}$ & 1.99 & 6.5 & 5.67 & 5.04 \\
\hline $\mathrm{TiO}_{2}$ & 0.21 & 1 & 0.7 & 0.64 \\
\hline $\mathrm{MgO}$ & 0.54 & 2.2 & 2.886 & 2.48 \\
\hline $\mathrm{MnO}$ & 0.09 & 0.11 & 0.06 & 0.1 \\
\hline $\mathrm{CaO}$ & 0.96 & 1.3 & 3.63 & 3.59 \\
\hline $\mathrm{Na}_{2} \mathrm{O}$ & 4.23 & 1.2 & 1.14 & 3.27 \\
\hline $\mathrm{K}_{2} \mathrm{O}$ & 3.59 & 3.7 & 3.97 & 2.8 \\
\hline $\mathrm{P}_{2} \mathrm{O}_{5}$ & 0.06 & 0.16 & 0.13 & 0.15 \\
\hline Total & 100.00 & 97.87 & 99.86 & 100.05 \\
\hline $\mathrm{Ni}$ & 7.40 & 55 & 58 & 47 \\
\hline $\mathrm{Cr}$ & 18.20 & 110 & 125 & 92 \\
\hline $\mathrm{Sc}$ & 5.28 & 16 & 15 & 14 \\
\hline $\mathrm{V}$ & 24.5 & 150 & 130 & 97 \\
\hline Cs & 8.33 & 15 & 5.16 & 4.9 \\
\hline $\mathrm{Ba}$ & 620 & 650 & 636 & 628 \\
\hline $\mathrm{Rb}$ & 140.16 & 160 & 125 & 82 \\
\hline $\mathrm{Sr}$ & 81.75 & 200 & 142 & 320 \\
\hline $\mathrm{Hf}$ & 2.41 & 5 & 6.3 & 5.3 \\
\hline $\mathrm{Zr}$ & 63.50 & 210 & 200 & 193 \\
\hline $\mathrm{Y}$ & 11.54 & 27 & 35 & 21 \\
\hline $\mathrm{Ta}$ & 12.48 & 1.28 & 1.12 & 0.9 \\
\hline $\mathrm{Nb}$ & 23.82 & 19 & 13 & 12 \\
\hline $\mathrm{Ga}$ & 20.49 & - & - & 17.5 \\
\hline $\mathrm{Cu}$ & 15.03 & - & - & 28 \\
\hline $\mathrm{Zn}$ & 66.65 & - & - & 67 \\
\hline $\mathrm{Pb}$ & 19.41 & 20 & 20 & 17 \\
\hline $\mathrm{Th}$ & 10.38 & 14.6 & 12.3 & 10.5 \\
\hline $\mathrm{U}$ & 2.39 & 3.1 & 2.7 & 2.7 \\
\hline $\mathrm{La}$ & 24.89 & 38.2 & 31.1 & 31 \\
\hline $\mathrm{Ce}$ & 52.22 & 79.6 & 66.7 & 63 \\
\hline $\operatorname{Pr}$ & 6.11 & 8.83 & - & 7.1 \\
\hline $\mathrm{Nd}$ & 22.15 & 33.9 & 27.4 & 27 \\
\hline
\end{tabular}




\begin{tabular}{ccccc} 
Continued & & & & \\
\hline $\mathrm{Sm}$ & 4.94 & 5.55 & 5.59 & 4.7 \\
$\mathrm{Eu}$ & 0.67 & 1.08 & 1.18 & 1 \\
$\mathrm{Gd}$ & 3.71 & 4.66 & - & 4 \\
$\mathrm{~Tb}$ & 0.49 & 0.774 & 0.85 & 0.7 \\
$\mathrm{Dy}$ & 2.45 & 4.68 & - & 3.9 \\
$\mathrm{Ho}$ & 0.48 & 0.991 & - & 0.83 \\
$\mathrm{Er}$ & 1.31 & 2.85 & - & 2.3 \\
$\mathrm{Tm}$ & 0.28 & 0.405 & - & 0.3 \\
$\mathrm{Yb}$ & 1.62 & 2.82 & 3.06 & 2 \\
$\mathrm{Lu}$ & 0.32 & 0.433 & 0.456 & 0.31 \\
$\mathrm{~K}_{2} \mathrm{O} / \mathrm{Na}{ }_{2} \mathrm{O}$ & 2.12 & 3.08 & 3.48 & 0.86 \\
$\mathrm{SiO} / \mathrm{Al} \mathrm{O}_{3}$ & 6.04 & 3.32 & 3.83 & 4.32 \\
$\mathrm{Th} / \mathrm{Sc}$ & 2.18 & 0.91 & 0.82 & 0.75 \\
$\mathrm{La} / \mathrm{Sc}$ & 6.65 & 2.38 & 2.07 & 2.21 \\
$\mathrm{Cr} / \mathrm{Th}$ & 1.91 & 7.53 & 10.16 & 8.76 \\
$\mathrm{Th} / \mathrm{U}$ & 4.40 & 4.71 & 4.56 & 3.89 \\
$\mathrm{Zr} / \mathrm{Sc}$ & 16.91 & 13.13 & 13.33 & -79 \\
$\Sigma \mathrm{REE}$ & 128 & 185 & - & \\
\hline
\end{tabular}

(1) [15] and [16]; (2) [17]; and (3) [18].

\subsection{Trace Elements}

The range and average value of selected trace elements in the metasediments are as follows (Table 3): $\mathrm{U}(0.4-4.8 \mathrm{ppm}, 2.39)$, Th (0.9 - $25.60 \mathrm{ppm}, 10.38), \mathrm{Ni}(0.1$ - 17.70 ppm, 7.40), Sr (37 - 124 ppm, 81.75), Ba (55 - 1228 ppm, 620.31), Sn (1.4 - 4.8), Be (1 - 11 ppm, 3.31), Li (2.6 - 48.50 ppm, 23.28), Rb (32 - 376.3 ppm, 140.16), Ta (0.5 - 65.20 ppm, 12.48), $\mathrm{Nb}(7.76-47.5 \mathrm{ppm}, 23.82)$ and $\mathrm{Cs}(0.8$ $33.30 \mathrm{ppm}, 8.33)$.

Trace elemental concentration of metasedimentary rocks are affected by several factors which could reflect various processes which are related to the formation of the protolith (such processes include composition of the source, weathering, flow sorting) or modification by diagenesis and metamorphism [19] and the variable trace element contents of the metasediments may reflect provenance differences, mineral fractionation during turbidity current deposition, or metamorphic effects [20]

Geochemical analytical result reveals an enhancement of $\mathrm{Ba}$ over $\mathrm{Rb}$ in a larger percentage of the metasediment which can be attributed to derivation from $\mathrm{K}$-feldspar rich protolith; this is supported by the relatively high values of $\mathrm{Ba}$ and $\mathrm{Rb}$. Ba relative enrichment coupled with the strong depletion of $\mathrm{Sr}$ relative to PAAS, NASC, UCC is in line with the general relative low abundance of $\mathrm{CaO}$, 
Table 3. Trace elemental concentration of metasediments.

\begin{tabular}{|c|c|c|}
\hline & Range (ppm) & Average(ppm) \\
\hline Mo & bdl-19.87 & 1.72 \\
\hline $\mathrm{Cu}$ & $1.0-54.900$ & 15.30 \\
\hline $\mathrm{Pb}$ & $5.58-25.20$ & 19.41 \\
\hline $\mathrm{Zn}$ & $9.1-139.60$ & 66.65 \\
\hline $\mathrm{Ag}$ & bdl-86.00 & 43.55 \\
\hline $\mathrm{Ni}$ & $0.10-17.70$ & 7.40 \\
\hline Co & bdl-11.70 & 4.21 \\
\hline As & Bdl- 2.20 & 1.31 \\
\hline $\mathrm{U}$ & $0.40-4.80$ & 2.39 \\
\hline Th & $0.90-25.60$ & 10.38 \\
\hline $\mathrm{Sr}$ & $37.00-124$ & 81.75 \\
\hline $\mathrm{Cd}$ & Bdl-0.23 & 0.13 \\
\hline $\mathrm{Sb}$ & Bdl-0.94 & 0.22 \\
\hline $\mathrm{Bi}$ & $0.04-2.08$ & 0.51 \\
\hline $\mathrm{V}$ & Bdl-57 & 24.5 \\
\hline $\mathrm{Cr}$ & Bdl-47 & 18.20 \\
\hline $\mathrm{Ba}$ & $55-1228$ & 620.31 \\
\hline $\mathrm{W}$ & $0.10-3.10$ & 0.73 \\
\hline $\mathrm{Zr}$ & $4.40-161.70$ & 63.50 \\
\hline Sn & $1.40-4.80$ & 2.69 \\
\hline $\mathrm{Be}$ & $1.00-11.00$ & 3.31 \\
\hline $\mathrm{Sc}$ & $0.90-21.50$ & $\begin{array}{c}5.28 \\
5.215\end{array}$ \\
\hline $\mathrm{Y}$ & $2.50-28.90$ & 11.54 \\
\hline $\mathrm{Hf}$ & $0.41-4.54$ & 2.41 \\
\hline $\mathrm{Li}$ & $2.60-48.50$ & 23.28 \\
\hline $\mathrm{Rb}$ & $32-376.30$ & 140.16 \\
\hline $\mathrm{Ta}$ & $0.50-65.20$ & 12.48 \\
\hline $\mathrm{Nb}$ & $7.76-47.5$ & 23.82 \\
\hline Cs & $0.80-33.30$ & 8.33 \\
\hline $\mathrm{Ga}$ & $13.52-25.68$ & 20.49 \\
\hline $\mathrm{Tl}$ & $0.12-2.39$ & 0.79 \\
\hline
\end{tabular}

*all values are in ppm except $\mathrm{Ag}$ (in ppb).

which implies that the source material of metasediments is plagioclase-poor.

$\mathrm{Ni}, \mathrm{Sc}, \mathrm{Cr}$ and $\mathrm{V}$ are compatible ferromagnesium trace elements. Compared to the UCC with values (in ppm) of 47, 92, 14 and 97 for $\mathrm{Ni}, \mathrm{Cr}, \mathrm{Sc}$ and $\mathrm{V}$ respec- 
tively, the NASC with values (in ppm) of 58, 125, 15 and 130 for Ni, Cr, Sc and V and PAAS with values (in ppm) of 55, 110, 16 and 150 for Ni, Cr, Sc and V; the metasediments in the study area are depleted in $\mathrm{Ni}, \mathrm{Cr}, \mathrm{Sc}$ and $\mathrm{V}$ with average values (in ppm) of 7, 18, 5 and 25 ppm respectively (Table 2).

\subsection{Provenance, Recycling and Maturity}

Due to the ability of transition elements to resist dispersion by secondary processes and their ability to strongly reflect the chemistry of the original protolith, it is suggested that protoliths in which these elements are abundant and compatible had significant contribution to the source of the metasediments [12]. Th, Sc and the REEs are thought to be less affected by sorting during sediment transportation and deposition as well as diagenesis and metamorphism hence high field strength elements and rare earth elements as well as Sc, Th and $\mathrm{Zr}$ are very useful in determination of maturity of the sediments as well as intensity of sorting during transportation and deposition amongst other uses [16] and [17].

[19] Explained that ratios of incompatible elements with similar hydrodynamic behavior should remain invariant and this is exemplified by the Th/Sc vs. Sc plots as well as the Zr/Sc vs. Sc plots (Figure 8 and Figure 9); which reveals normal to lower concentrations of $\mathrm{Zr}$ is an indication infers immaturity to semi-maturity for the metasediments studied [8].

Provenance discrimination diagram based on $\mathrm{K} / \mathrm{Rb}$ ratios (Figure 12, [21]) reveals derivation of metasediments from an acidic to intermediate magmatic protolith with minimal input from mafic sources. This is supported by the provenance signature plot of [11] which indicates the samples are from a felsic igneous provenance (Figure 11).

A plot of $\mathrm{Th} / \mathrm{Sc}$ versus $\mathrm{Zr} / \mathrm{Sc}$ can reflect the amount of sedimentary sorting and recycling [22]; Th/Sc generally increases with sedimentary maturity and or with the supply of acidic detritus [17]; it is an indicator of chemical differentiation and $\mathrm{Zr} / \mathrm{Sc}$ ratio measures the degree of sediment recycling. First-cycle sediments show a simple positive correlation between $\mathrm{Th} / \mathrm{Sc}$ and $\mathrm{Zr} / \mathrm{Sc}$, whereas

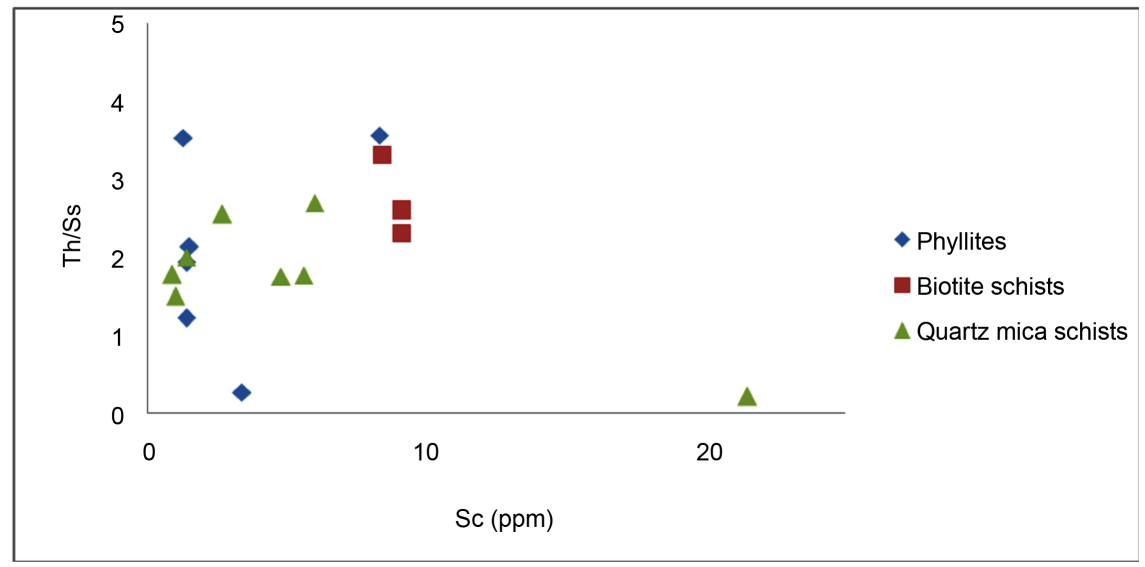

Figure 8. Th/Sc vs Sc for metasediments in thestudy area. 


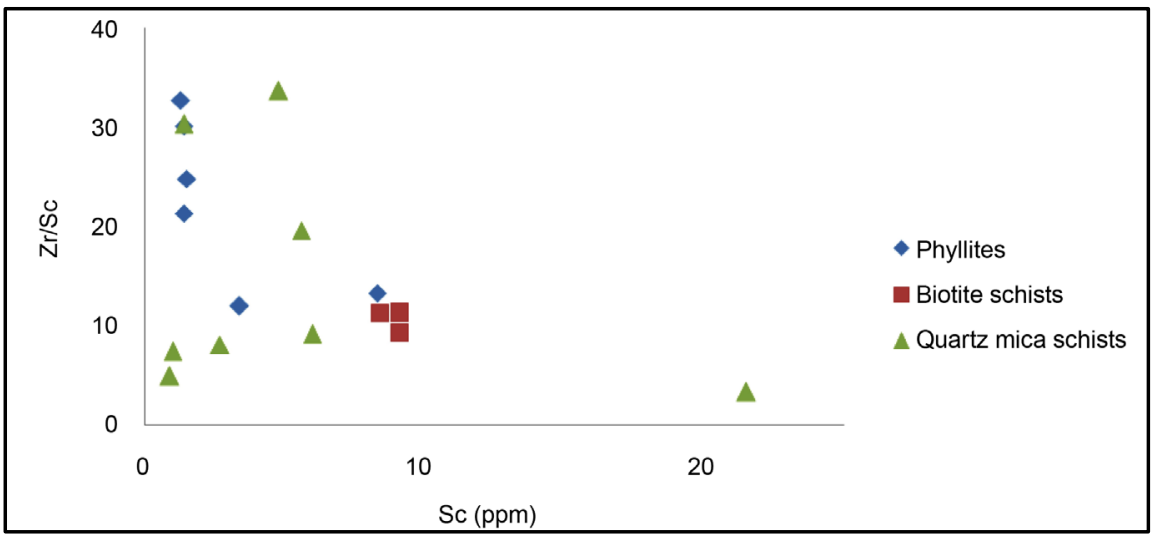

Figure 9. $\mathrm{Zr} / \mathrm{Sc}$ vs Sc for metasediments in the study area.

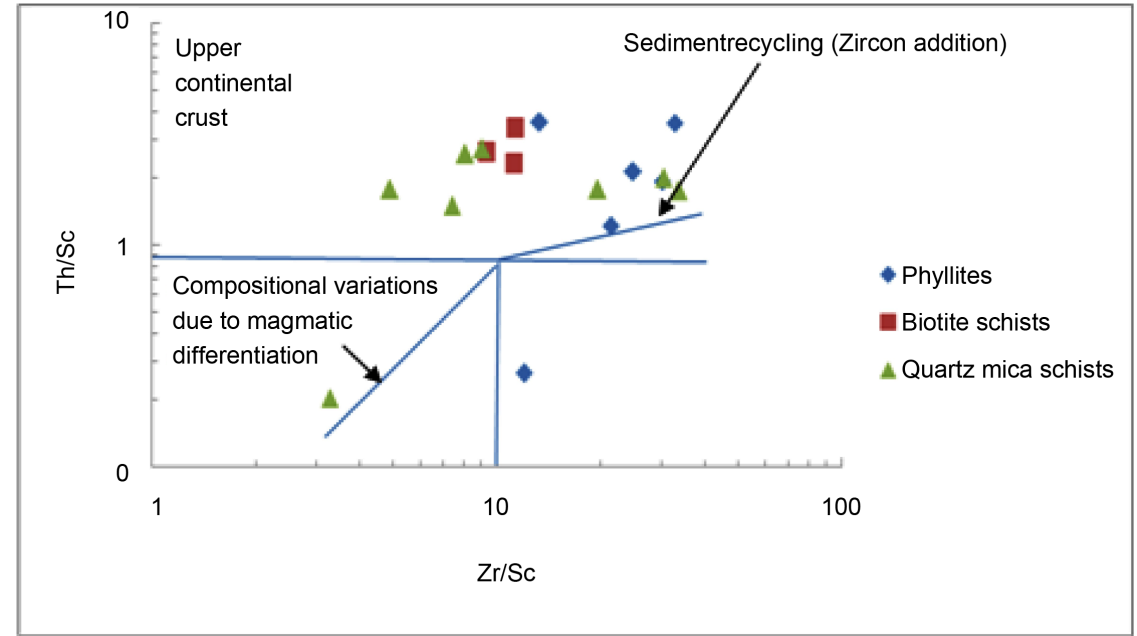

Figure 10. Plot of $\mathrm{Th} / \mathrm{Sc}$ versus $\mathrm{Zr} / \mathrm{Sc}$ for metasediments in the study.

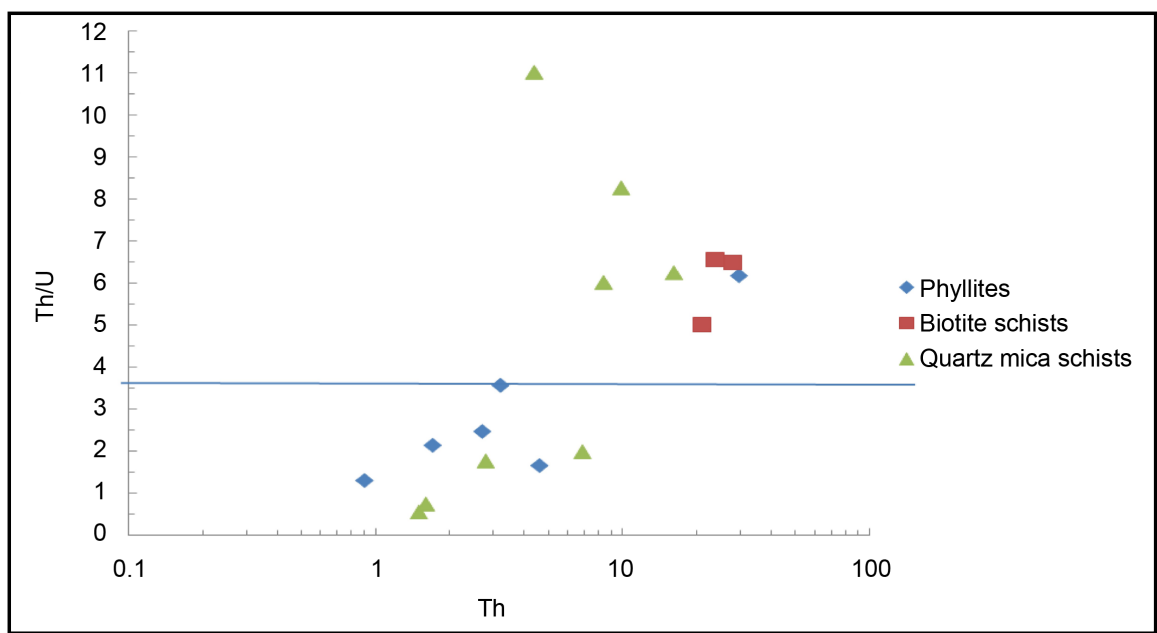

Figure 11. Plots of Th/U versus Th for the studied metasediments.

additionally recycled sediments usually show increase in $\mathrm{Zr} / \mathrm{Sc}$ more rapidly than $\mathrm{Th} / \mathrm{Sc}$. High $\mathrm{Zr} / \mathrm{Sc}$ ratio are indicative of high level of sediment recycling 
and low $\mathrm{Zr} / \mathrm{Sc}$ ratio indicative of sediments which are affected less by sediment recycling (Figure 10, Figure 11).

Metasediments mainly follow the magmatic compositional variation trend on the $\mathrm{Zr} / \mathrm{Sc}$ plot, with slight displacement towards higher $\mathrm{Zr} / \mathrm{Sc}$ ratios $(>10)$, which is suggestive of varying degrees of sediment reworking and sorting.

$\mathrm{Th} / \mathrm{U}$ values greater than 4.0 points to intense weathering in source areas or high level of sediment recycling. Th/ $\mathrm{U}$ ratio in the metasediments range from 1 11 which is indicative of high levels of sediment recycling. Furthermore, a plot of Th/U vs Th diagram (Figure 12, [23]) further explains the varying degree of weathering the metasediments have undergone. Some of the samples have high $\mathrm{Th} / \mathrm{U}$ ratios above that of the upper crust while some have $\mathrm{Th} / \mathrm{U}$ ratios approaching that of depleted mantle sources (Figure 12).

\subsection{Rare Earth Elements}

The range and average concentration of selected rare earth elements in whole rock pegmatites is as follows (Table 4): $\mathrm{La}(2.8$ - $59.7 \mathrm{ppm}, 24.89)$, Ce (6.6 115.75 ppm, 52.22), Nd (3 - 45.8 ppm, 22.15), Sm (0.7 - 9.6 ppm, 4.94), Eu (0.2 1.9 ppm, 0.67), Gd (0.7 - 8.5 ppm, 3.71) and Yb (0.3 - 3.7 ppm, 1.62). EREEs 20 263 ppm, average 121 ppm.

Rare earth elements were normalization revealed varying negative Eu anomaly (Figures 13(a)-(c)); light rare-earth elements enrichment in respect to heavy rare-earth elements and positive $\mathrm{LaN} / \mathrm{YbN}$ indicative of higher fractionation of light than heavy REE as is typical of terrigenous rocks [24].

\section{Conclusions}

Metasediments of parts of Igangan Sheet 240 NW have been studied; their geology and geochemistry have been delineated. The occurrence quartzite as layers within some of the weathered schists is an indication of sediment deposition under unstable flow regimes with heavy and light sediments deposited

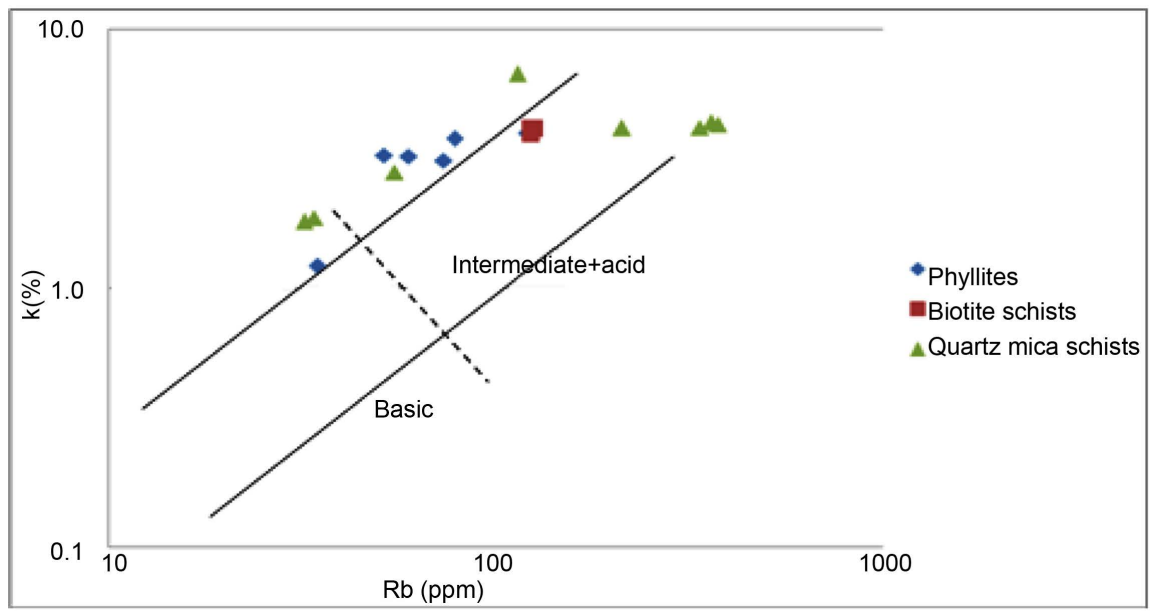

Figure 12. K-Rb plot for studied metasediments. 


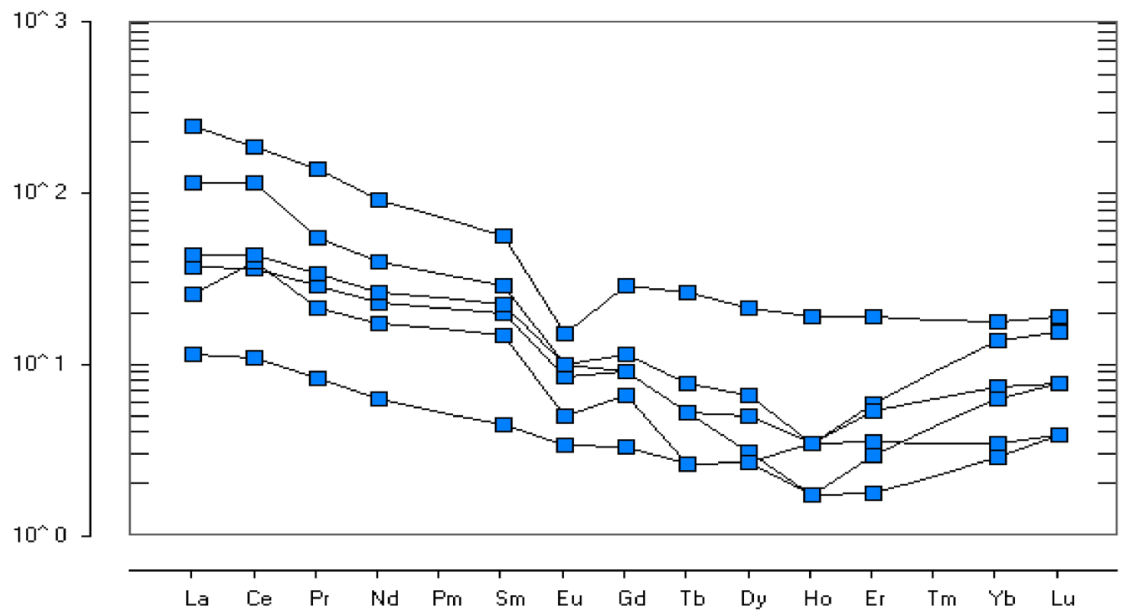

(a)

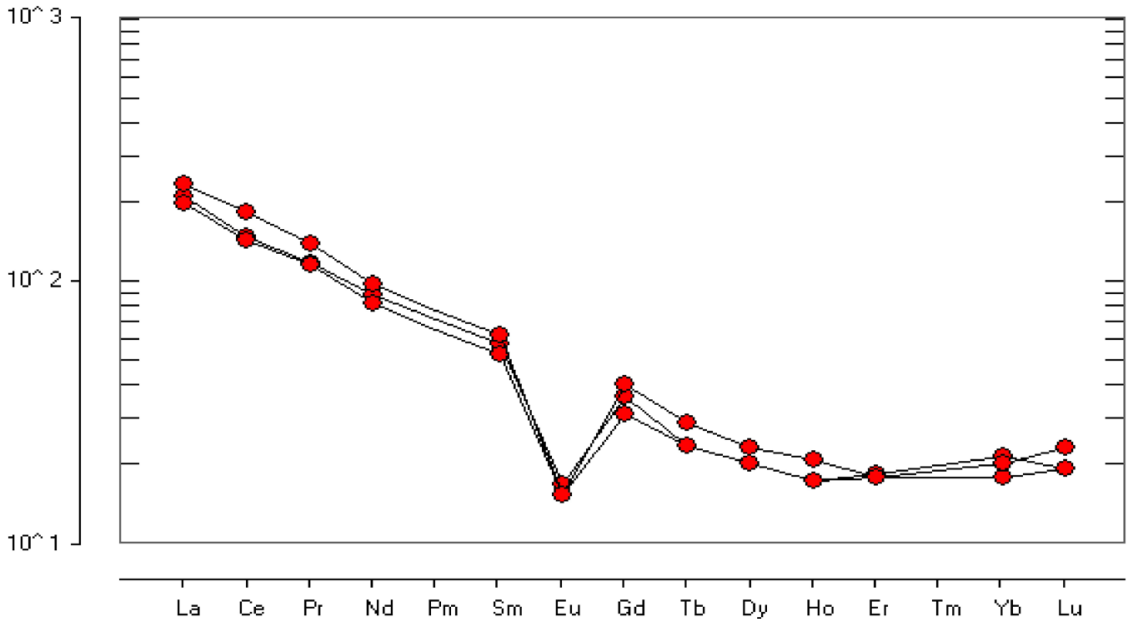

(b)

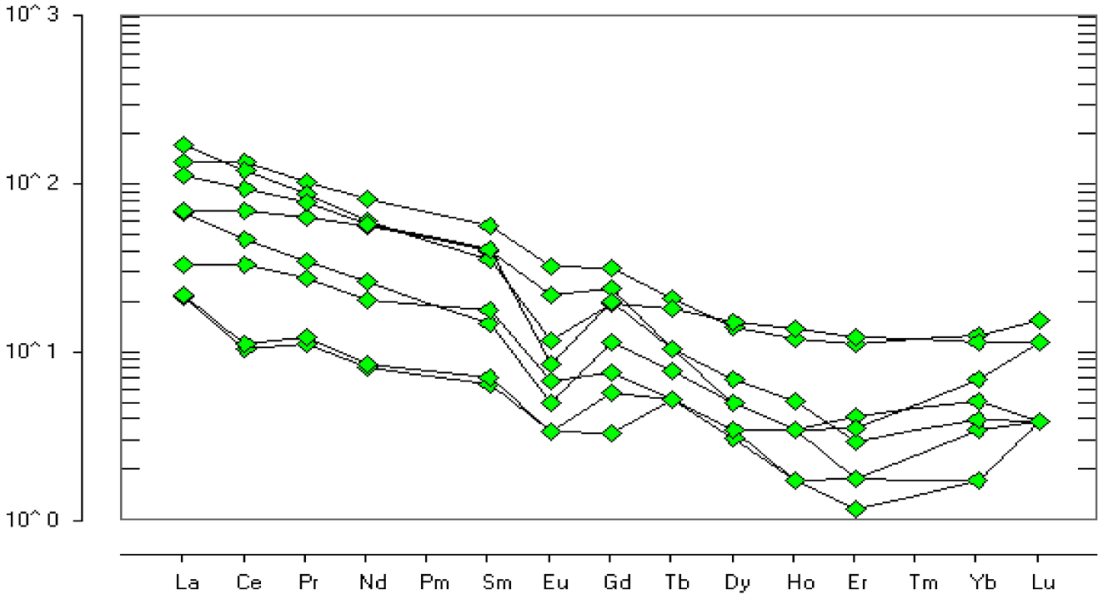

(c)

Figure 13. (a) Condrite normalization plot for phyllites (values after [25]); (b) Condrite normalization plot for biotite quartz schist (values after [25]); (c) Condrite normalization plot for quartz muscovite schist (values after [25]). 
Table 4. Rare Earth elements of metasediments.

\begin{tabular}{ccc}
\hline & Range $(\mathrm{ppm})$ & Average (ppm) \\
\hline $\mathrm{La}$ & $2.8-59.7$ & 24.89 \\
$\mathrm{Ce}$ & $6.6-115.75$ & 52.22 \\
$\mathrm{Pr}$ & $0.8-13.3$ & 6.11 \\
$\mathrm{Nd}$ & $3-45.8$ & 22.15 \\
$\mathrm{Sm}$ & $0.7-9.6$ & 4.94 \\
$\mathrm{Eu}$ & $0.2-1.9$ & 0.67 \\
$\mathrm{Gd}$ & $0.7-8.5$ & 3.71 \\
$\mathrm{~Tb}$ & Bdl-1.1 & 0.49 \\
$\mathrm{Dy}$ & $0.7-6$ & 2.45 \\
$\mathrm{Ho}$ & Bdl-1.2 & 0.48 \\
$\mathrm{Er}$ & $0.2-3.2$ & 1.31 \\
$\mathrm{Tm}$ & Bdl- 0.5 & 0.28 \\
$\mathrm{Yb}$ & $0.3-3.7$ & 1.62 \\
$\mathrm{Lu}$ & Bdl-0.6 & 0.32 \\
\hline
\end{tabular}

at different times.

The metasediments are arkosic to greywacke para-schists and ortho-schists derived from high potassic sources with different regimes of sediment deposition evident by quartzite sandwiched between mica schists in some areas. CIA and $\mathrm{Th} / \mathrm{U}$ values indicate mild to moderate chemical weathering of an igneous to intermediate source rocks with high level of sediment recycling.

\section{Acknowledgements}

This study is part of the PhD thesis of OOG; OOG acknowledges the research grant and $\mathrm{PhD}$ scholarship received from the African University Commission (AUC) to pursue his studies. Olajide-Kayode, J.O., Popoola, O., Sobhy, M., Oladele, A. and others who assisted during the field work are appreciated.

Anonymous reviewers whose contributions have made this manuscript better are also appreciated for their constructive criticism.

\section{References}

[1] Okonkwo, C.T. and Winchester, J.A. (1996) Geochemistry and Geotectonic Setting of Precambrian amphibolites and Granitic Gneisses in the Jebba Area, Southwestern Nigeria. Journal of Mining Geology, 32, 11-18.

[2] Rahaman, M.A. (1976) Review of the Basement Geology of South-Western Nigeria. In: Kogbe, C.A., Ed., Geology of Nigeria, 2nd Edition, Elizabethan Publishers, Lagos, 41-58.

[3] Adedoyin, A.D., Adekeye, J.I.D. and Ojo, O.J. (2014) Geochemical Composition and Petrogenesis of Schists and Amphibolites of Parts of Sheets 203 (Lafiagi) SW 
and 224 (Osi) NW, Southwestern Nigeria. Ilorin Journal of Science, 1.

[4] Oluyide, P.O., Nwajide, C.S. and Oni, A.O. (1998) The Geology of the Ilorin Area. Nigerian Geological Survey Bulletin, No. 42, 84 p.

[5] Sifeta, K., Roser, B.P. and Kimura, J.I. (2005) Geochemistry, Provenance, and Tectonic Setting of Neoproterozoic metavolcanic and Metasedimentary Units, Werri Area, Northern Ethiopia. Journal of African Earth Sciences, 41, 212-234. https://doi.org/10.1016/j.jafrearsci.2005.04.004

[6] de Lima, M.M.C., da Silva, T.R., Ferreira, V.R. and da Silva, J.M.R. (2014) Metasedimentary Rocks of the Northern Portion of the Macururé Domain, Sergipano Belt, Northeastern Brazil. Estudos Geológicos, 24.

[7] Akinola, O.O. and Okunlola, O.A. (2014) Compositional Characteristics and Petrogenetic Features of Metasediments of Ijero-Ekiti Area, Southwestern Nigeria. RMZ $M \& G, 61,221-230$.

[8] Obaje, N.G. (2009) Geology and Mineral Resources of Nigeria. Lecture Notes in Earth Sciences, 120. https://doi.org/10.1007/978-3-540-92685-6

[9] Pettijohn, F.J. (1975) Sedimentary Rocks. Harper and Row, New York, 628 p.

[10] Herron, M.M. (1988) Geochemical Classification of Terrigenous Sands and Shales from Core or Log Data. Journal of Sedimentary Petrology, 58, 820-829.

[11] Roser, B.P. and Korsch, R.J. (1988) Provenance Signatures of Sandstone-Mudstone Suite Determined Using Discrimination Function Analysis of Major-Element Data. Chemical Geology, 67, 119-139. https://doi.org/10.1016/0009-2541(88)90010-1

[12] El-Bialy, M.Z. (2013) Geochemistry of the Neoproterozoic Metasediments of Malhaq and Um Zariq Formations, Kid Metamorphic Complex, Sinai, Egypt: Implications for Source-Area Weathering, Provenance, Recycling, and Depositional Tectonic Setting. Lithos, 175-176, 68-85. https://doi.org/10.1016/j.lithos.2013.05.002

[13] Roser, B.P., Cooper, R.A., Nathan, S. and Tulloch, A.J. (1996) Reconnaissance Sandstone Geochemistry, Provenance, and Tectonic Setting of the Lower Paleozoic Terranes of the West Coast and Nelson, New Zealand. New Zealand Journal of Geology and Geophysics, 39, 1-16. https://doi.org/10.1080/00288306.1996.9514690

[14] Nesbitt, H.W. and Young, G.M. (1982) Early Proterozoic Climates and Plate Motions Inferred from Major Element Chemistry of Lutites. Nature, 299, 715-717. https://doi.org/10.1038/299715a0

[15] Taylor, S.R. and McLennan, S.M. (1985) The Continental Crust: Its Composition and Evolution. Blackwell Scientific Publication, Carlton, 312 p.

[16] McLennan, S.M. (2001) Relationships between the Trace Element Composition of Sedimentary Rocks and Upper Continental Crust. Geochemistry, Geophysics, Geosystems, 2, 1021-1024. https://doi.org/10.1029/2000GC000109

[17] Gromet, L.P., Dymek, R.E., Haskin, L.A. and Korotev, R.L. (1984) The "North American Shale Composite": Its Composition, Major and Trace Element Characteristics. Geochimica et Cosmochimica Acta, 48, 2469-2482. https://doi.org/10.1016/0016-7037(84)90298-9

[18] Rudnick, R.L. and Gao, S. (2003) Composition of the Continental Crust. In: Rudnick, R.L., Ed., The Crust, Elsevier-Pergamon, Oxford, 1-64. https://doi.org/10.1016/B0-08-043751-6/03016-4

[19] Fralick, P.W. and Kronberg, B.I. (1997) Geochemical Discrimination of Clastic Sedimentary Rock Sources. Sedimentary Geology, 113, 111-124. https://doi.org/10.1016/S0037-0738(97)00049-3 
[20] Condie, K.C., Wilks, M., Rosen, D.M. and Zlobin, V.L. (1991) Geochemistry of Metasediments from the Precambrian Hapschan Series, Eastern Anabar Shield, Siberia. Precambrian Research, 50, 37-47. https://doi.org/10.1016/0301-9268(91)90046-D

[21] Floyd, P.A and Leveridge, B.E. (1987) Tectonic Environment of the Devonian Gramscatho Basin, South Cornwall: Framework Mode and Geochemical Evidence from Turbiditic Sandstones. Journal of the Geological Society of London, 144, 531-542. https://doi.org/10.1144/gsigs.144.4.0531

[22] McLennan, S.M., Taylor, S.R., McCulloch, M.T. and Maynard, J.B. (1990) Geochemical and Nd-Sr Isotopic Composition of Deep-Sea Turbidites: Crustal Evolution and Plate Tectonic Associations. Geochimica et Cosmochimica Acta, 54, 2015-2050. https://doi.org/10.1016/0016-7037(90)90269-Q

[23] McLennan, S.M., Hemming, S., McDaniel, D.K. and Hanson, G.N. (1993) Geochemical Approaches to Sedimentation, Provenance and Tectonics. In: Johnsson, M.J. and Basu, A., Eds., Processes Controlling the Composition of Clastic Sediments: Geological Society of America, Special Paper, Vol. 284, 21-40.

https://doi.org/10.1130/SPE284-p21

[24] Condie, K.C. (1993) Chemical Composition and Evolution of the Upper Continental Crust: Contrasting Results from Surface Samples and Shales. Chemical Geology, 104, 1-37. https://doi.org/10.1016/0009-2541(93)90140-E

[25] Sun, S.S. and McDonough, W.F. (1989) Chemical and Isotopic Systematics of Oceanic Basalts: Implications for Mantle Composition and Processes. In: Saunders, A.D. and Norry, M.J., Eds., Magmatism in the Ocean Basins, Geological Society, London, Special Publications No. 42, 313-345.

https://doi.org/10.1144/GSL.SP.1989.042.01.19 